\title{
Potensi Pendirian Baitul Mal Wa Tamwil (BMT) di Desa Tolang Julu Kecamatan Sayur Matinggi Kabupaten Tapanuli Selatan
}

\author{
Rindah Febriani Harahap ${ }^{1}$, Rodame Monitorir Napitupulu² \\ 1,2Institut Agama Islam Negeri Padangsidimpuan \\ 1,2Jalan T. Rizal Nurdin Km. 4,5 Sihitang, Padangsidimpuan \\ 1 rindahfebrianio6@gmail.com \\ 2 napitupulurm@gmail.com
}

\begin{abstract}
Abstrak
Baitul Mal Wa Tamwil (BMT) memiliki arti penting bagi pembangunan ekonomi serta menjadi inti kekuatan ekonomi yang berbasis kerakyatan, kehadirannya sangat dibutuhkan terkhusus pada masyarakat yang memiliki usaha mikro yang dapat dikembangkan, sehingga dengan dorongan tersebut peneliti tertarik untuk meneliti potensi pendirian BMT di Desa Tolang Julu Kecamatan Sayur Matinggi Kabupaten Tapanuli Selatan. Tujuan dari penelitian ini adalah untuk mengetahui potensi pendirian BMT di Desa Tolang Julu Kecamatan Sayur Matinggi Kabupaten Tapanuli Selatan. Penelitian ini adalah penelitian lapangan dengan pendekatan kualitatif, bersifat deskriptif. Subjek penelitian ini adalah masyarakat Desa Tolang Julu yang memiliki usaha mikro dan membutuhkan dana. Sumber data yang digunakan yaitu data primer dan sekunder. Hasil penelitian menunjukan bahwa di Desa Tolang Julu Kecamatan Sayur Matinggi Kabupaten Tapanuli selatan memiliki potensi untuk didirikannya BMT. Kelemahan dan ancaman yang ada dapat diminimalisirkan dengan strategi pada matriks SWOT yaitu strategi SO, strategi WO, strategi ST, strategi WT.
\end{abstract}

Kata Kunci: Potensi, BMT, Analisis SWOT.

\begin{abstract}
Baitul Mal Wa Tamwil (BMT) has an important meaning for economic development as well as being the core of a community-based economic strength, its presence is needed especially for people who have micro-businesses that can be developed, so with this encouragement researchers are interested in researching the potential for establishing BMTs in Tolang Village. Julu, Sayur Matinggi District, South Tapanuli Regency. The purpose of this study was to determine the potential for establishing BMT in Tolang Julu Village, Sayur Matinggi District, South Tapanuli Regency. This research is a field research with a qualitative approach, is descriptive in nature. The subjects of this research are the people of Tolang Julu Village who have micro-businesses and need funds. The data sources used are primary and secondary data. The results showed that in Tolang Julu Village, Sayur Matinggi District, South Tapanuli Regency, it has the potential to establish BMT. The existing weaknesses and threats can be minimized with a strategy in the SWOT matrix, namely the SO strategy, the WO strategy, the ST strategy, the WT strategy.
\end{abstract}

Keywords: Potential, BMT, SWOT analysis. 
141 Potensi Pendirian Baitul Mal Wa Tamwil (BMT) di Desa Tolang Julu Kecamatan Sayur Matinggi Kabupaten Tapanuli Selatan

\section{PENDAHULUAN}

Undang-Undang Dasar 1945 menempatkan koperasi sebagai soko guru perekonomian Indonesia. Oleh karena itu, koperasi merupakan salah satu perusahaan yang mungkin untuk berkembang secara ekonomis. Dengan demikian koperasi diharapkan mampu meningkatkan kesejahteraan ekonomi masyarakat dan anggotanya, serta memberikan kontribusi kepada pembangunan dan pertumbuhan ekonomi. Koperasi adalah salah satu bagian dari LKM (Lembaga Keuangan Mikro) (Zainul Arifin, 2000).

Selain Lembaga Keuangan Mikro (LKM), juga sudah tumbuh Lembaga Keuangan Mikro Syariah (LKMS) dan berkembang sejak awal 1990-an di Indonesia. Lembaga ini menjalankan kegiatan usaha simpan pinjam dengan prinsip syariah. Lembaga Keuangan Mikro Syariah (LKMS) yang telah memiliki badan Hukum berupa koperasi yaitu dengan nama Baitul Mảl Wat Tamwỉl (BMT) yang diartikan ke dalam dua kata, yaitu baitul mảl dan baitul tamwil. BMT telah berkembang pesat sejak Oktober tahun 1995 seiring adanya UndangUndang No.7 Tahun 1992 yang kemudian diubah menjadi Undang-Undang No. 10 Tahun 1998 tentang Lembaga Keuangan Syariah.

Kecamatan Sayur Matinggi merupakan salah satu kecamatan yang ada di Kabupaten Tapanuli Selatan. Luas kecamatan Sayur Matinggi ini sebesar 376,55 km². Dengan jumlah kelurahan atau desa sebanyak 19 dan total jumlah penduduk 24.465 jiwa (Kantor Camat Kecamatan Sayur Matinggi). Berdasarkan data dari Dinas Koperasi Perindustrian dan Perdagangan Tapanuli Selatan 14 November 2018 di Kabupaten Tapanuli Selatan terdapat 23 koperasi dan semuanya dapat dikatakan koperasi non syariah. Kecamatan Sayur Matinggi memiliki hanya 1 koperasi yang terletak di Kelurahan Sayur Matinggi tersebut. Berdasarkan uraian tersebut masyarakat yang menjadi anggota koperasi hanya sekitar 0,00004\% (Data Perkembangan Koperasi Tahun 2017 dari BPS Tapanuli Selatan).

Dalam wawancara dengan bapak Fuad Daulay selaku Kepala Desa Tolang Kecamatan Sayur Matinggi Kabupaten Tapanuli Selatan, 6 April 2019 disebutkan bahwa Desa Tolang Julu adalah salah satu desa yang terletak di Kecamatan Tapanuli Selatan. Jarak dari kantor kepala desa ke ibokota Kecamatan sekitar 9,00 km dengan topografi desa yaitu datar. Jumlah masyarakat sebanyak 260 Kepala Keluarga (KK) yang terdiri dari 494 (Laki-laki) dan 520 (perempuan) dan berjumlah 1.014 orang. Masyarakat di Desa Tolang Julu Kecamatan Sayur Matinggi Kabupaten Tapanuli Selatan semuanya menganut agama Islam. Berdasarkan hasil wawancara dengan Ibu Ami selaku masyarakat setempat, beliau mengatakan: "Masyarakat Desa Tolang Julu Kecamatan Sayur Matinggi Kabupaten Tapanuli Selatan ini berjumlah sangatlah banyak, dimana penduduk semuanya menganut agama Islam”. Masyarakat mayoritas bekerja sebagai petani dan 40\% home industri. Ciri khas usaha disana yaitu adanya berdiri pasar di Desa Tolang Julu apalagi setiap hari Rabu sangat ramai, karna masyarakatJISFIM: Journal of Islamic Social Finance Management, Volume 1, No 1 Tahun 2020 http://jurnal.iain-padangsidimpuan.ac.id/index.php/JISFIM 
masyarakat desa lain berdatangan untuk memenuhi ekonominya. Dipasar ini banyak usaha mikro kecil, mikro kecil yang sangat menyebar adalah penjualan alat tajam seperti pisau, parang. Pangsa pasar dari usaha mikro kecil parang ini 20\% dan sudah sangat menyebar luas seperti ke Panyabungan, Padangsidimpuan, Sibolga, Medan, serta Bukit Tinggi.

Masyarakat Tolang juga mempunyai suatu kerajinan yang terbuat dari rotan yang diolah menjadi keranjang buah, keranjang alat kesenian, keranjang sebagai dekorasi interior rumah, serta membuat kursi. Usaha mikro ini juga sudah terkenal luas. Pangsa pasar dari usaha mikro kecil ini 10\% dan sudah menyebar ke masyarakat lain seperti, Padangsidimpuan, Sibolga dan Panyabungan. Banyak lagi terdapat usaha mikro kecil di pasar Desa Tolang Julu Kecamatan Sayur Matinggi Kabupaten Tapanuli Selatan seperti pedagang-pedagang baju, sayur-mayur, kelontong bahkan pengusaha karet. Dengan adanya usaha mikro yang dapat dibudidayakan sehingga dapat menyejahterakan ekonomi masyarakat, demikian pula masyarakat banyak mengeluh karena tidak adanya satu pun lembaga keuangan yang ikut serta atau andil dalam menumbuhkan kesejahteraan ekonomi di Desa Tolang Julu Kecamatan Sayur Matinggi Kabupaten Tapanuli Selatan ini.

Berdasarkan hasil wawancara dengan:

Bapak Ibrahim Daulay selaku sekdes Tolang Julu, beliau mengatakan:

Tidak ada satu pun lembaga keuangan yang berdiri di desa ini bahkan belum pernah ada. Pengusaha kecil yang berada di desa ini memulai usahanya dengan keterbatasan modal sendiri, karena tidak ada lembaga keuangan yang mendukung, sedikit banyak dari mereka memperoleh modal dari penggadaian barang ataupun meminjam dengan sesama masyarakat.

Irma Harahap selaku pemilik usaha mikro setempat, beliau mengatakan:

Saya setiap harinya menjual alat tajam, pergi ke desa-desa, pergi ke pasar, saya juga membuka usaha ini dirumah. Saya mau memperluas usaha dengan menambahnya, tapi keterbatasan modal.

Melihat banyaknya pelaku usaha mikro di Tapanuli Selatan khususnya Desa Tolang Julu yang terbatas akan permodalan yang kurang memadai maka peneliti tertarik untuk melihat potensi pendirian Baitul Mảl Wa Tamwỉl (BMT). Berdasarkan uraian diatas, peneliti memandang penelitian ini penting untuk dilakukan.

\section{KAJIAN TEORITIS}

Baitul Mảl Wa Tamwil (BMT) mengembangkan usaha-usaha produktif untuk meningkatkan pendapatan pengusaha kecil dan anggota. Pendirian Baitul Mảl Wa Tamwỉ (BMT) diyakini merupakan faktor penting dalam upaya menanggulangi kemiskinan serta pembangunan ekonomi pedesaan. Pengembangan BMT akan menumbuh kembangkan dan meningkatkan kegiatan ekonomi pengusaha kecil berdasarkan prinsip syariah.

Setiap desa sudah pasti memiliki banyak potensi didalamnya. Potensi yang dimiliki oleh sebuah desa dapat dijadikan sebagai kekuatan dan peluang untk melakukan pembangunan desa yang lebih baik. Potensi yang dimaksud dalam penelitian ini potensi masyarakat yaitu keterbatasan usaha kecil dan mikro dalam berhubungan dengan perbankan,

JISFIM: Journal of Islamic Social Finance Management, Volume 1, No 1 Tahun 2020 http://jurnal.iain-padangsidimpuan.ac.id/index.php/JISFIM 
143 Potensi Pendirian Baitul Mal Wa Tamwil (BMT) di Desa Tolang Julu Kecamatan Sayur Matinggi Kabupaten Tapanuli Selatan

mayoritas desa Tolang Julu beragama Islam, jenis pekerjaan masyarakat mayoritas petani dan wirausahaan seperti jualan baju, bengkel, kedai kopi, rumah makan, kaki lima, yang membutuhkan pembiayaan agar dapat meningkatkan usaha yang dijalankan. Kondisi ini yang menyebabkan mereka kesulitan untuk datang ke lembaga perbankan karena kinerja kerja lembaga perbankan tidak terjangkau usaha dengan skala kecil. Hal ini adalah salah satu BMT untuk menarik masyarakat menjadi nasabah.

Baitul mảl sesungguhnya sudah ada sejak masa Rasulullah Saw, yaitu ketika kaum Muslimi mendapatkan ghanimah pada perang badar. Baitul mảl pada masa Rasullah Saw mempunyai pengertian sebagai pihak yang menangani setiap harta benda kaum Muslimin, baik berupa pendapatan maupun pengeluaran (Gusfahmi, 2007).

Baitul Mảl Wa Tamwỉl adalah balai usaha mandiri terpadu yang isinya berintikan bait al-mảl wa at-tamwíl dengan kegiatan mengembangkan usaha-usaha produktif dan investasi dalam meningkatkan kualitas kegiatan ekonomi pengusaha kecil bawah dan kecil dengan antara lain mendorong kegiatan menabung dengan menunjang pembiayaan kegiatan ekonominya. Selain itu, BMT juga bisa menerima titipan zakat, infak, dan sedekah, lalu menyalurkannya sesuai dengan peraturan dan amanatnya. Menurut Abdul Qadim Zallum, menyatakan bawa "Baitul mảl adalah lembaga atau pihak yang mempunyai tugas khusus menangani segala harta umat, baik berupa pendapatan maupun pengeluaran negara" (Abdul Qadim Zallum, 1983).

BMT bersifat terbuka, indenpenden, berorientasi pada pengembangan tabungan dan pembiayaan untuk mendukug nisnis ekonomi yang produktif bagi anggota dan kesejahteraan sosial masyarakat sekitar, terutama usaha mikro dan fakir miskin. Peran BMT dimasyarakat sebagai berikut:

1) Motor penggerak ekonomi dan sosial masyarakat banyak

2) Ujung tombak pelaksanaan sistem ekonomi syariah

3) Penghubung antara kaum aghỉnả (kaya) dan kaum duảfa (miskin)

4) Sarana pendidikan informal untuk mewujudkan prinsip hidup yang barakah, ahsanu'amalả dan salảm melalui spiritual communication dengan dzikir qalbỉyah ilahiyảh (Kautsar Riza Salman, 2012).

BMT sesuai namanya terdiri dari fungsi utama, yaitu :

1) Baitul tamwil (rumah pengembangan harta), melakukan kegiatan pengembangan usahausaha produktif dan investasi dalam mengingkatkan kualitas ekonomi pegusaha mikro dan kecil dengan antara lain mendorong kegiatan menabung dan menunjang pembiayaan kegiatan ekonomi.

2) Baitul mảl (rumah harta), menerima titipan dana zakat, infak, dan sedekah serta mengoptimalkan distribusinya sesuai dengan peraturan dan amanahnya.

JISFIM: Journal of Islamic Social Finance Management, Volume 1, No 1 Tahun 2020 http://jurnal.iain-padangsidimpuan.ac.id/index.php/JISFIM 
Adapun fungsi BMT sebagai berikut :

1) Mengidentifikasi, memobilisasi, mengorganisir, mendorong, dan mengembangkan potensi serta kemampuan ekonomi anggota, kelompok usaha anggota muamalat (Pokusma) dan kerjanya,

2) Mempertinggi kualitas SDM anggota dan Pokusma menjadi lebih profesional dan islami sehingga semakin utuh dan tangguh menghadapi tentangan global, dan

3) Menggalang dan mengorganisir potensi masyarakat dalam rangka meningkatkan kesejahteraan anggota (Andri Soemitro, 2009).

BMT bertujuan mewujudkan kehidupan keluarga masyarakat di sekitar BMT yang selamat, damai, dan sejahtera. Visi BMT adalah mewujudkan kualitas masyarakat di sekitar BMT yang selamat, damai, dan sejahtera dengan mengembangkan lembaga dan usaha BMT serta POKUSMA (Kelompok Usaha Muamalah) yang maju berkembang, terpercaya, aman, transpasaran dan berhati-hatian. Misi BMT adalah mengembangkan POKUSMA (Kelompok Usaha Muamalah) dan BMT yang maju dan berkembang, terpercaya, amana, nyaman, transparan, dan berhati-hatian sehingga terwujud kualitas masyarakat di sekitar BMT yang selamat, damai, dan sejahtera.

Untuk mencapai tujuan, visi, misi BMT, ada beberapa hal yang harus dilakukan, yaitu:

1) Menegembangkan kegiatan simpan pinjam dengan prinsip bagi hasil atau syariah

2) Mengembangkan lembaga dan bisnis Kelompok Usaha Muamalah yaitu kelompok simpan pinjam yang khas binaan BMT, dan

3) Jika BMT telah berkembang cukup mapan, memprakarsai pengembangan Badan Usaha Sektor Rill (BUSRIL) dari sejumlah POKUSMA sebagai badan usaha pendamping (Nurul Huda dkk, 2016).

BMT berdasarkan pancasila dan Undang-Undang Dasar 1945 serta berlandaskan syariah Islam, keimanan, keterpaduan (kaffảh), kekeluargaan/koperasi, kebersamaan, kemandirian dan profesionalisme. Secara Hukum BMT berpayung pada koperasi tetapi sistem operasionalnya tidak jauh berbeda dengan BMT seperti apa yang ada di dalam Bank Syariah. Oleh karena itu berbadan hukum koperasi, maka BMT haru tunduk pada Undang-Undang Nomor 25 Tahun 1992 tentang Perkoperasian dan PP Nomor 9 Tahun 1995 tentang pelaksanaan usaha simpan pinjam oleh koperasi. Juga dipertegas oleh KEP. MEN Nomor 91 Tahun 2004 tentang Koperasi Jasa Keuangan Syariaah Undang-Undang tersebut sebagai payung berdirinya BMT (Lembaga Keuangan Mikro Syariah).

Dasar hukum berdirinya Baitul Mảl Wa Tamwil (BMT) terdapat dalam surah AtTaubah ayat 60 yang artinya:

Sesungguhnya zakat-zakat itu, hanyalah untuk orang- orang fakir, orang-orang miskin, pengurus-pengurus zakat, Para mu'allaf yang dibujuk hatinya, untuk (memerdekakan) budak, orang-orang yang berhutang, untuk jalan Allah dan untuk mereka yang sedang 
145 Potensi Pendirian Baitul Mal Wa Tamwil (BMT) di Desa Tolang Julu Kecamatan Sayur Matinggi Kabupaten Tapanuli Selatan

dalam perjalanan, sebagai suatu ketetapan yang diwajibkan Allah, dan Allah Maha mengetahui lagi Maha Bijaksana.(QS. At Taubah ayat 60) (Departemen Agama RI, 2006).

Ayat yang diatas menggambarkan bahwa ada yang keberatan tentang pembagian Nabi SAW. sambil berkata bahwa beliau tidak ada karena membagikan kepada para pengembala dan lain-lain. Ayat ini membenarkan Nabi itu sambil menjelaskas bahwa sesungguhnya zakatzakat, bukan untuk mereka yang mencemoohkan itu, tetapi ia hanyalah dibagikan untuk orang-orang fakir, orang-orang miskin, pengelolah-pengelolahannya yakni yang mengumpulkan zakat, mencari, dan memerdekakan para hamba sahaya, dan orang-orang berutang bukan dalam kedurhakaan kepada Allah, dan disalurkan juga pada sabilillah dan orang-orang yang kehabisan bekal yang sedang didalam perjalanan. Semua itu sebagai suatu ketetapan yang diwajibkan Allah, dan Allah Maha Mengetahui dalam menetapkan ketentuanketentuanNya. Karena itu, akat tidak boleh dibagikan kecuali kepada yang ditetapkanNya itu selama mereka ada (M. Quraish Shihab, 2002).

Dasar hukum berdirinya Baitul Mảl Wa Tamwỉl (BMT) juga terdapat dalam surah AtTaubah ayat 103 yang artinya"

Ambillah zakat dari sebagian harta mereka, dengan zakat itu kamu membersihkan dan mensucikan mereka dan mendoalah untuk mereka. Sesungguhnya doa kamu itu (menjadi) ketenteraman jiwa bagi mereka. dan Allah Maha mendengar lagi Maha mengetahui. (QS. At Taubah ayat 103) (Dapartemen Agama RI).

Ayat ini menyatakan bahwa mereka yang mengakui dosanya sewajarnya dibersihkan dari noda dan, karena sebab utamak ketidakikutan mereka ke medan juang adalah ingin bersenang-senang dengan harta yang mereka miliki atau disebabkan hartalah yang menghalangi mereka berangkat, ayat ini memberi tuntunan tentang cara membersihkan diri, dan untuk disedekahkan kepada yang berhak. Dapat juga dikatakan bahwa ayat yang lalu berbicara tentang sekelompok orang yang imannya masih lemah, yang mencampurkanbaurkan amal baik dan buruk dalam kegiatannya. Mereka diharapkan dapat diampuni Allah salah satu pengampunanNya adalah melalui sedekah dan pembayaran zakat. Karena itu diini Nabi Muhammad SAW diperintahkan: ambillah atas nama Allah sedekah, yakni harta berupa zakat dan sedekah, yang hendaknya mereka serahkan dengan penuh kesungguhan dan ketulusan hati, dari sebagian harta mereka, bukan seluruhnya, bukan pula sebagian besar, dan tidak juga yang terbaik, dengannya, yakni dengan harta yang engkau ambil itu, engkau membersihkan harta dan jiwa lagi menggembangkan harta mereka, dan berdoalah untk mereka guna menunjukan restumu terhadap mereka dan memohon keselamatan dan kesejahteraan bagi mereka. Sesungguhnya doamu itu adalah sesuatu yangg dapat menjadi ketentraman jiwa bagi mereka yang selama ini gelisah dan takut akibat dosaJISFIM: Journal of Islamic Social Finance Management, Volume 1, No 1 Tahun 2020 http://jurnal.iain-padangsidimpuan.ac.id/index.php/JISFIM 
dosa yang mereka lakukan. Dan sampaikanlah kepada mereka bahwa Allah Maha Mendengar lagi Maha Mengetahui (M. Quraish Shihab, 2002).

Tujuan penelitian ini dilakukan adalah untuk mengetahui potensi pendirian Baitul Mảl Wa Tamwil (BMT) di Desa Tolang Julu Kecamatan Sayur Matinggi Kabupaten Tapanuli Selatan. Untuk mencapai tujuan dari penelitian ini, maka peneliti menggunakan analisis SWOT. SWOT merupakan metode yang digunakan untuk menggambarkan kondisi dan mengevaluasi suatu masalah, yang berdasarkan faktor internal dan eksternal yaitu, Strenght, Weakness, Opportunity, Threats.

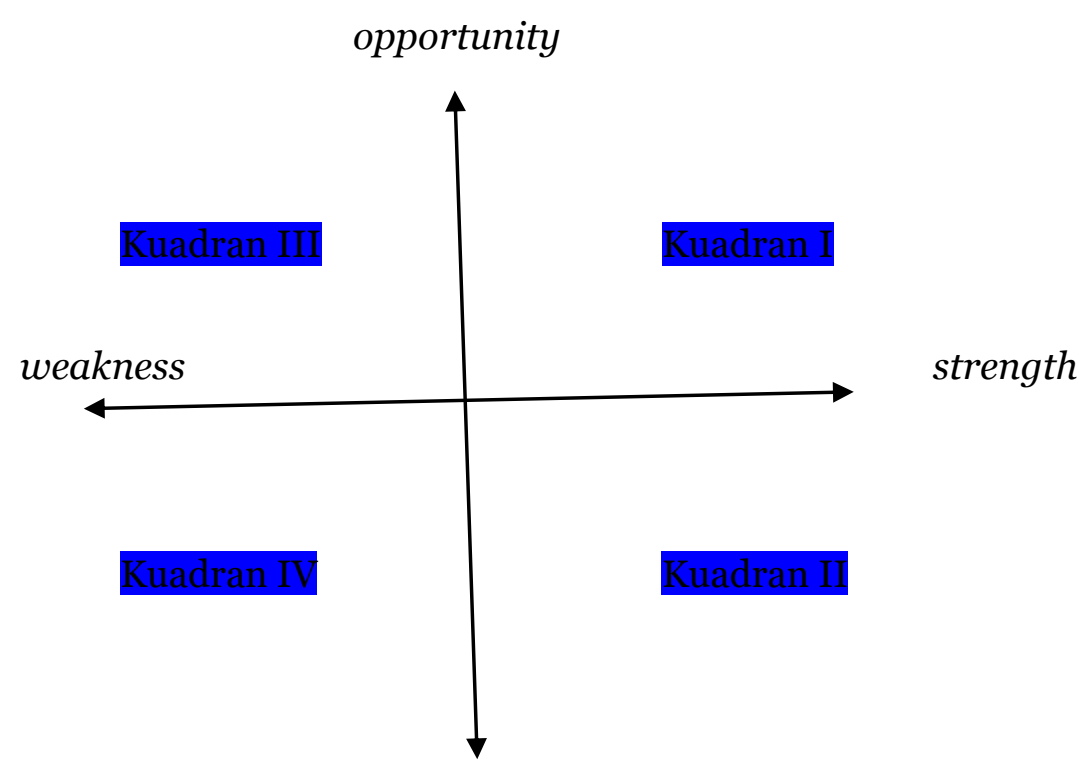

threath

\section{Gambar 1. Analisis SWOT}

Posisi Kuadran I (Positif, Positif) menandakan sebuah organisasi yang kuat dan berpeluang (Freddy Rangkuti, 2014). Rekomendasi strategi yang diberian adalah Progresif, artinya organisasi dalam kondisi prima dan mantap sehingga sangat dimungkinkan untuk terus melakukan ekspantasi, memperbesar pertumbuhan dan meraih kemajuan secara maksimal.

Posisi Kuadran II (Positif, Negatif) menandakan sebuah organisasi yang kuat namun menghadapi tantangan yang menghadapi tantangan yang besar. Rekomendasi strategi yang diberikan adalah Diversifikasi Strategi, artinya organisasi dalam kondisi mntap namun menghadapi sejumlah tantangan berat sehingga diperkirakan roda organisasi akan mengalami kesulitan untuk terus berputar bila hanya bertumpu pada strategi sebelumya. Oleh karenanya, organiasi disarankan untuk segera memperbanyak ragam strategi taktisnya. 
Posisi Kuadran III (Negatif, Positif) menandakan seuah organisasi yangg lemah namun sangat berpeluang. Rekomendasi strategi yang diberikan adalah Ubah Strategi, artinya organisasi disarankan untuk mengubah strategi sebelumnya, sebab, strategi yang lama dikhawatirkan sulit untuk dapat menangkap peluang yang ada sekaligus memperbaiki kinerja organisasi.

Posisi Kuadran IV (Negatif, Negatif) menandakan sebuah organisasi yang lemah dan menghadapi tantangan yang besar. Rekomendasi strategi yang diberikan adalah Strategi Bertahan, artinya kondisi internal organisasi berada pada pilihan dilematis. Oleh karenanya organisasi disarankan untuk menggunakan strategi bertahan, mengendalikan kinerja internal agar tidak semakin terperosok. Strategi ini dipertahankan sambil terus berupaa membenahi diri.

Untuk menguatkan penelitian ini, maka peneliti mengambil penelitian terdahulu yang berkaitan dengan potensi dan pendirian BMT, yaitu:

Tabel 1

Penelitian Terdahulu

\begin{tabular}{|c|c|c|c|}
\hline No & $\begin{array}{l}\text { Nama } \\
\text { Peneliti }\end{array}$ & $\begin{array}{l}\text { Judul } \\
\text { Penelitian }\end{array}$ & Hasil penelitian \\
\hline 1 & $\begin{array}{l}\text { Elfa Murdiana, } \\
\text { (Jurnal } \\
\text { Penelitian } \\
\text { Vol.10, No.2, } \\
\text { Agustus 2016) }\end{array}$ & \begin{tabular}{lr}
\multicolumn{2}{|l|}{ Menggagas } \\
Payung & Hukum \\
Baitul & Mal Wa \\
Tamwil & $(\mathrm{BMT})$ \\
sebagai & Koperasi \\
Syariah & dalam \\
Bingkai & Ius \\
Constituendum
\end{tabular} & $\begin{array}{l}\text { BMT merupakan lembaga keuangan } \\
\text { yang dimana dapat menumbuhkan } \\
\text { ekonomi masyarakat. } \\
\text { menggunakan prinsip syariah. BMT } \\
\text { merupakan lembaga keuangan mikro } \\
\text { syariah yang secara faktual telah } \\
\text { memberikan pengaruh positif terhadap } \\
\text { berlangsungnya } \\
\text { ekonomi. }\end{array}$ \\
\hline 2 & $\begin{array}{lr}\text { Ahmad } & \text { Wira } \\
\text { dan } & \text { Septia } \\
\text { (Jurnal } & \text { Islam, } \\
\text { Vol.14, } & \text { No.1 } \\
\text { Juni 2015) }\end{array}$ & \begin{tabular}{lr}
\multicolumn{3}{|l|}{ Potensi } & Pendirian \\
BMT & di \\
Kecamatan \\
Sungai \\
Kabupaten \\
Pasaman Barat
\end{tabular} & $\begin{array}{l}\text { Tedapat potensi pendirian BMT di } \\
\text { Kecamatan Sungai Aur Kabupaten } \\
\text { Pesaman Barat dari hasil analisis } \\
\text { SWOT penilaian terhadap faktor } \\
\text { internal kekuatan dan kelemahan yang } \\
\text { dimiliki BMT secara umum } \\
\text { menunjukkan hasil yang positif yaitu } \\
\text { terdapat selisih antara kekuatan dan } \\
\text { kelemahan yang dimiliki oleh BMT } \\
\text { sebesar 1. Sedangkan dari faktor } \\
\text { eksternal diketahui bahwa terdapat } \\
\text { selisih total penilaian antara peluang } \\
\text { dan ancaman yaitu ssebesar o,77. } \\
\text { Sehingga dapat diketahui dari matriks } \\
\text { SWOT bahwa posisi BMT berada pada } \\
\text { kuadrat 1 posisi ini menandakan bahwa } \\
\text { BMT yang akan didirikan mempunyai } \\
\text { kekuatan dan berpeluang sehigga } \\
\text { sanga memungkinkan untuk } \\
\text { mendirikan BMT di tempat penelitian. }\end{array}$ \\
\hline
\end{tabular}

JISFIM: Journal of Islamic Social Finance Management, Volume 1, No 1 Tahun 2020

http://jurnal.iain-padangsidimpuan.ac.id/index.php/JISFIM 


\begin{tabular}{|c|c|c|c|}
\hline 3 & $\begin{array}{l}\text { Novrizal dan } \\
\text { Widayat, } \\
\text { (Jurnal } \\
\text { Pendidikan } \\
\text { Ekonomi dan } \\
\text { Bisnis, Vol.6 } \\
\text { No.1, 2018) } \\
\end{array}$ & $\begin{array}{l}\text { Strategi } \\
\text { Menyiasati } \\
\text { Perubahan Bisnis: } \\
\text { Kasus BMT Al- } \\
\text { Ittihad }\end{array}$ & $\begin{array}{l}\text { Adanya straegi yang dilakukan oleh } \\
\text { pihak BMT guna menumbuhkan } \\
\text { perekonomian masyarakat agar } \\
\text { ekonomi semakin membaik yaitu } \\
\text { dalam bidang keuangan, anggota } \\
\text { organisasi, eksternal dan internal. }\end{array}$ \\
\hline 4 & $\begin{array}{l}\text { Rulyjanto } \\
\text { Podungge, } \\
\text { (Jurnal Al- } \\
\text { Mizan, } \\
\text { iaingorontalo.a } \\
\text { c.id. Vol.10 } \\
\text { No.1, Juni } \\
\text { 2014) }\end{array}$ & $\begin{array}{l}\text { Potensi BMT ( } \\
\text { Baitul Mảl } \\
\text { Wattamwil), } \\
\text { Pesantren Guna } \\
\text { Menggerakkan } \\
\text { Ekonomi Syariah } \\
\text { Masyarakat }\end{array}$ & $\begin{array}{l}\text { Pesantren dapat berperan aktif dalam } \\
\text { kehidupan sosial, ekonomi bahkan } \\
\text { politik. Fonsadasi motor penggerak } \\
\text { adalah koperasi BMT. Fleksibilitas } \\
\text { BMT sebagai lembaga bisnis jasa } \\
\text { keuangan syariah dan organ inti sel } \\
\text { bisnis sektor riil, sinergi dan simultan. }\end{array}$ \\
\hline 5 & $\begin{array}{l}\text { Rahmiati, } \\
\text { (Skripsi: UIN } \\
\text { Sultan Syarif } \\
\text { Kasim Riau, } \\
\text { 2012) }\end{array}$ & $\begin{array}{lr}\text { Studi } & \text { Tentang } \\
\text { Potensi } & \text { BMT Al- } \\
\text { Amin } & \text { di } \\
\text { Kecamatan } & \text { Bukit } \\
\text { Raya PekanBaru }\end{array}$ & $\begin{array}{l}\text { Adanya potensi pertumbuhan ekonomi } \\
\text { masyarakat yang bersal dari BMT } \\
\text { tersebut, dimana tiap tahunnya } \\
\text { nasabah menambah dan modal serta } \\
\text { jumlah aset juga begitu. Dengan posisi } \\
\text { BMT berada di sekitar pasar dan home } \\
\text { industri. }\end{array}$ \\
\hline
\end{tabular}

Perbedaan dan persamaannya dengan penelitian ini adalah sebagai berikut:

1. Elfa membahas tentang payung Menggagas Payung Hukum Baitul Mảl Wa Tamwil (BMT) sebagai Koperasi Syariah dalam Bingkai Ius Constituendum sedangkan peneliti membahas tentang potensi pendirian BMT di Kelurahan Tolang Julu Kecamatan Sayurmatinggi Kabupaten Tapanuli Selatan. Persamaannya sama-sama membahas tentang BMT

2. Ahmad Wira membahas tentang potensi pendirian BMT di Kecamatan Sungai Aur Kabupaten Pasaman Barat dengan menggunakan analisis SWOT sedangkan peneliti membahas tentang potensi pendirian di Kecamatan Sayur Matinggi Kabupaten Tapanuli Selatan dengan menggunakan analisis deskriptif dan analisis SWOT.

3. Novrizal dan Widayat membahas tentang Strategi Menyiasati Perubahan Bisnis: Kasus BMT Al-Ittihad sedangkan peneliti membahas tentang potensi pendirian di Kecamatan Sayur Matinggi Kabupaten Tapanuli Selatan. Persamaannya sama-sama membahas tentang BMT.

4. Ruliyjanto Pondungge membahas tentang potensi BMT pesantren guna menggerakkan ekonomi syariah dimasyarakat dimana melihat potensi dengan membandingkan konvensional dan syariah sedangkan peneliti membahas tentang potensi pendirian di Kecamatan Sayur Matinggi Kabupaten Tapanuli. Persamaannya sama-sama membahas tentang potensi dalam BMT.

5. Rahmiati membahas tentang Studi Tentang Potensi BMT Al-Amin di Kecamatan Bukit Raya PekanBaru sedangkan peneliti membahas tentang potensi pendirian di 
149 Potensi Pendirian Baitul Mal Wa Tamwil (BMT) di Desa Tolang Julu Kecamatan Sayur Matinggi Kabupaten Tapanuli Selatan

Kecamatan Sayur Matinggi Kabupaten Tapanuli Selatan. Persamaannya sama-sama membahas tentang potensi dalam BMT.

\section{METODE PENELITIAN}

Penelitian ini berlokasi di Desa Tolang Julu Kecamatan Sayur Matinggi Kabupaten Tapanuli Selatan. Dalam penelitian ini peneliti menggunakan jenis penelitian kualitatif yang bersifat deskriptif. Subjek penelitian adalah subjek yang dituju untuk diteliti oleh peneliti (Suharsimi Arikunto, 2001). Dalam penelitian ini yang menjadi subjek penelitian adalah masyarakat Desa Tolang Kecamatan Sayur Matinggi Kabupaten Tapanuli Selatan yang berjumlah 260 Kepala Keluarga. Dari beberapa literatur atau bacaan tentang metodologi penelitian dapat diperoleh informasi bahwa besarnya sampel tidak boleh kurang (paling tidak) dari $10 \%$ populasi sementara ada pula yang menyatakan minimal $5 \%$ dari populasi (Burhan Bungin, 2011). Jadi jumlah informan dalam penelitian ini adalah 26 informan. Penentuan subjek penelitian menggunakan pertimbangan purposive sampling, maka penentuan sampel pada penelitian ini dipilih dengan kriteria yaitu; Informan masyarakat Desa Tolang yang kekurangan dana atau modal pada usahanya; Informan seorang yang mempunyai usaha mikro kecil seperti penjual alat tajam, benda terbuat dari rotan, serta pedagang di Desa Tolang; dan Pembeli dari usaha mikro kecil.

Analisis data adalah sebuah cara untuk mengolah data menjadi informasi agar karakteristik data tersebut mudah dipahami dan bermanfaat untuk solusi permasalahan, terutama hal yang berkaitan dengan penelitian. Setelah data terkumpul, maka akan dilaksanakan pengolahan data dan analisis data dengan metode analisis deskriptif dan analisis SWOT. Tujuan analisis data adalah proses mengatur urutan data, mengorganisasikannya ke dalam suatu pola, kategori dan satuan uraian dasar. Pekerjaan analisis data dalam hal ini ialah mengatur, mengurutkan, mengelompokkan, memberikan kode, dan mengategorikannya (Lexy Jmoleong, 2004).

Analisis SWOT adalah analisis kondisi internal maupun kondisi eksternal suatu organisasi yang selanjutnya akan digunakan sebagai dasar untuk merancang strategi dan program kerja. Analisis internal meliputi penilaian terhadap faktor kekuatan (stregth), dan kelemahan (weakness). Sementara, analisis eksternal mencakup faktor peluang (opportunity) dan tantangan (threath)( Freddy Rangkuti, 2011). Strategi BMT dalam usaha mikro digunakan tabel external analysis factor summary (EFAS) dan internal analysis factor summary (IFAS), langkah-langkahnya sebagai berikut:

a. Dalam sel Opportunities (O), buatlah peluang eksternal yang dihadapi oleh perusahaan.

b. Dalam sel Threats (T), buatlah ancaman eksternal yang dihadapi oleh perusahaan. 
c. Dalam sel Strengths (S), buatlah kekuatan yang dimiliki perusahaan (baik yang ada sekarang atau yang akan datang)

d. Dalam sel Weaknesses (W), buatlah kelemahan yang dimiliki oleh perusahaan.

e. Buatlah kemungkinan strategi dari perusahaan berdasarkan pertimbangan kombinasi empat set faktor strategi berikut.

Strategi SO dibuat berdasarkan jalan pikiran perusahaan, yaitu dengan menggunakan seluruh kekuatan untuk memanfaatkan peluang. Dalam strategi ini maksudnya dalam pendirian Baitul mảl Wa Tamwỉ (BMT) ini memanfaatkan dan menggunakan kekuatan dan peluang yang ada di masyarakat Desa Tolang Julu Kecamatan Sayur Matinggi Kabupaten Tapanuli Selatan sebagai potensi besar terhadap pendirian Baitul Mảl Wa Tamwỉl (BMT).

Strategi ST adalah strategi untuk menggunakan kekuatan yang dimiliki perusahaan dengan cara menghindari ancaman. Dalam strategi ini maksudnya dengan adanyanya kekuatan yang dimiliki masyarakat Desa Tolang Julu Kecamatan Sayur Matinggi Kabupaten Tapanuli Selatan dapat menghindari, meminimalisir ancaman yang akan muncul dalam pendirian Baitul Mảl Wa Tamwỉl (BMT) sehingga tidak mempengaruhi potensi terebut.

Strategi WO diterapkan berdasarkan pemanfaatan peluang yang ada, dengan mengatasi kelemahan-kelemahan yang dimiliki. Dalam strategi ini maksudnya dengan banyaknya peluang yang dimiliki dalam pendirian Baitul Mảl Wa Tamwỉl (BMT) ini menutupi kelemahan yang ada. Sehingga menjadi potensi dalam pendirian Baitul Mảl Wa Tamwỉ (BMT) di Desa Tolang Julu Kecamatan Sayur Matinggi Kabupaten Tapanuli Selatan ini.

Strategi WT didasarkan pada kegiatan yang bersifat defentif dan ditunjukan untuk meminimalkan kelemahan yang ada serta menghindari ancaman. Dalam strategi ini maksudnya tidak membiarkan kelemahan dan ancaman yang nantinya memepengaruhi potensi yang ada. Maka gunakanlah potensi tersebut untuk memimalkan kelemahan yang ada serta menghindari ancaman yang dapat mempengaruhi pendirian Baitul Mảl Wa Tamwỉl (BMT) di Desa Tolang Julu Kecamatan Sayur Matinggi Kabupaten Tapanuli Selatan.

Selanjutnya, dengan menggunakan faktor strategis (eksternal maupun internal). Transfer pluang dan ancaman (tahap 1 dan 2) dari tabel EFAS serta tambahkan kekuatan dan kelemahan (tahap 3 dan 4) dan tabel IFAS ke dalam sel sesuai dengan matriks SWOT. Berdasarkan pendekatan tersebut, kita dapat membuat berbagai kemungkinan alternatif strategi (SO, ST, WO, WT) 
151 Potensi Pendirian Baitul Mal Wa Tamwil (BMT) di Desa Tolang Julu Kecamatan Sayur Matinggi Kabupaten Tapanuli Selatan

Tabel 2

Matriks SWOT

\begin{tabular}{|l|l|l|}
\hline \multicolumn{1}{|r|}{ IFAS } & STRENGTHS & WEAKNESSES \\
EFAS & & \\
\hline OPPORTUNITIES & & \\
\hline THREATHS & & \\
& & \\
\hline
\end{tabular}

\section{HASIL DAN PEMBAHASAN}

Struktur Organisasi Pemerintahan Desa Tolang Julu adalah sebagai berikut

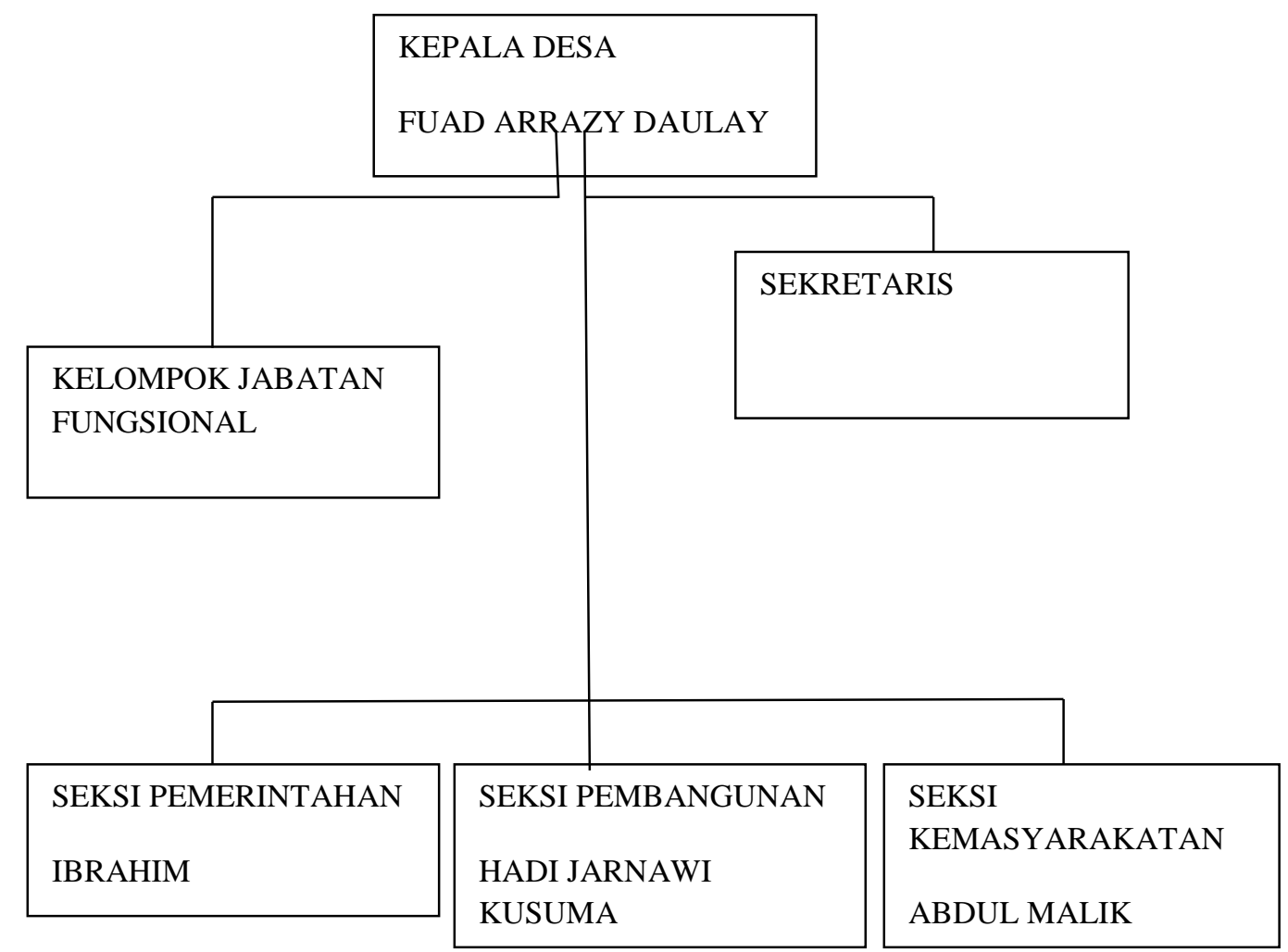

Gambar 2. Struktur Organisasi

JISFIM: Journal of Islamic Social Finance Management, Volume 1, No 1 Tahun 2020 http://jurnal.iain-padangsidimpuan.ac.id/index.php/JISFIM 
Desa Tolang Julu merupakan bagian dari 19 desa di Kecamatan Sayur Matinggi dan berjumlah 211 desa di Kabupaten Tapanuli Selatan dengan luas wilayah mencapai 6.030,47 km² . Desa Tolang julu berada di pinggiran Jalan Lintas Sumatera. Jarak desa Tolang Julu ke Ibukota Kecamatan yaitu 9,00 km. Adapun batas-batas wilayahnya adalah sebagai berikut:

1) Sebelah Utara Berbatasan dengan : Sipange Godang

2) Sebelah Selatan Berbatasan dengan : Tolang Jae

3) Sebelah Timur Berbatasan dengan : Mandailing Natal

4) Sebelah Barat Berbatasan dengan : Mondang

Sebagian besar wilayah Desa Tolang Julu Kecamatan Sayur Matinggi Kabupaten Tapanuli Selatan merupakan lahan persawahan dan perkebunan masyarakat.

\section{Tabel 3}

Peruntukan Lahan

\begin{tabular}{|c|l|c|}
\hline No & \multicolumn{1}{|c|}{ Peruntukan Lahan } & Luas (Ha) \\
\hline 1 & Persawahan & \\
\hline 2 & Perkebunan & \\
\hline 3 & Hutan Tanaman Rakyat & \\
\hline 4 & Pemukinan Masyarakat & \\
\hline 5 & Kolam/ Perikanan & \\
\hline 6 & $\begin{array}{c}\text { Perkantor/ Sarana Sosial } \\
\text { a. Kantor Kepala Desa }\end{array}$ & \\
\hline
\end{tabular}

Berdasarkan hasil verifikasi data kependudukan yang telah dilakukan oleh pemerintah Desa Tolang Julu pada bulan Desember 2018, keadaan penduduk Desa Tolang Julu yaitu dengan jumlah penduduk sebanyak 1.014 jiwa dengan kepala keluarga sebanyak 260 KK, jumlah laki-laki sebanyak 494 jiwa, jumlah perempuan sebanyak 520 jiwa. Masyarakat Desa Tolang Julu mayoritas beragama Islam dengan jumlah 1.014 jiwa. Kondisi ekonomi Desa Tolang Julu merupakan daerah pertanian, perkebunan, dan home industry. Lahan peruntukan pertanian dan perkebunan sangan luas di Desa Tolang Julu, tetapi banyak diantara masyarakat yang home indusrtri JISFIM: Journal of Islamic Social Finance Management, Volume 1, No 1 Tahun 2020 http://jurnal.iain-padangsidimpuan.ac.id/index.php/JISFIM 
153 Potensi Pendirian Baitul Mal Wa Tamwil (BMT) di Desa Tolang Julu Kecamatan Sayur Matinggi Kabupaten Tapanuli Selatan

yaang didukung dengan adanya kerajinan serta pasar yang telah dikenal luasa oleh masyarakat lainnya.

Kondisi sosial budaya masyarakat Desa Tolang masih sangat kental dengan adat istiadat dan tradisi peniggalan leluhur. Masyarakat Desa Tolang Julu lebih mengutamakan Agama dibandingkan dengan kebiasaan istiadat dan tradisi peninggalan leluhur. Apabila istiadat dan tradisi peninggalan leluhur itu tidak sesuai dengan Agama maka dihapuskan. Salah satu kebiasaan masyarakat Desa Tolang Julu ini yaitu gotong royong. Kebiasaan tersebut seperti kebiasaan menjenguk orang sakit, meninggal dunia, pesta perkawina yaitu masyarakat membuat sebuah organisasi STM (Serikat Tolong Menolong) di Desa Tolang Julu sebagai wadah untk menyalurkan gotong-royong tersebut.

Hasil wawancara peneliti tentang potensi pendirian Baitul Maal Wa Tamwil (BMT) dengan masyarakat Desa Tolang adalah sebagai berikut:

\section{Strenght (Kekuatan)}
a. Proses Pendirian Mudah
b. Memberikan Manfaat
c. Prosedur Pembiayaan Mudah
d. Memiliki Jangkauan Kepala Usaha Kecil

\section{Weakness (Kelemahan)}
a. Belum Populer Dikalangan Masyarakat
b. Modal Masih Terbatas
c. Sumber Daya Manusia Masih Lemah
d. Sistem dan Prosedur yang Mengatur Belum Baku

\section{Opportunities (Peluang)}
a. Mayoritas Penduduk Muslim
b. Jenis Pekerjaan Masyarakat yang Mayoritas Usaha Kecil dan Petani
c. Adanya Kebutuhan Modal
d. Sebagian Besar Masyarakat masih pada usia yang cukup Produktif
e. Keterbatasan Usaha Kecil Dalam Berhubungan Dengan Lembaga Perbankan.
f. Adanya Dukungan Masyarakat Untuk Pendirian BMT

\section{Threat (Ancaman)}
a. Ketidaktahuan Masyarakat Tentang BMT
b. Kurangnya Kejujuran Masyarakat 


\section{KESIMPULAN}

Hasil dari wawancara yang dilakukan peneliti terhadap mayarakat desa Tolang Julu guna mengetahui potensi pendirian Baitul Maal Wa Tamwil (BMT) di Desa Tolang Julu Kecamatan Sayur Matinggi Kabupaten Tapanuli Selatan dengan hasil deskriptif dan melihat dari analisis SWOT (Strength, Weakness, Opportunity, Threat) yaitu kekuatan, kelemahan, peluang dan ancaman. Kekuatan (Strenght) pendirian BMT yaitu jenis pekerjaan masyarakat yang bermayoritas usaha- usaha mikro, home industry, petani, pangsa pasar yang sudah diketahui masyarakat lain, serta belum adanya lembaga keuangan syariah yang beroperasi di daerah peneliti dan adanya dukungan dari masyarakat setempat. Kelemahan (Weakness) pendirian BMT yaitu ketidaktahuan masyarakat tentang lembaga keuangan apalagi yang berbasis syariah, karena kurangnya sosialisasi di daerah peneliti, permodalan yang masih terbatas dan lemah. Peluang (Opportunity) pendirian BMT yaitu jenis pekerjaan masyarakat yang bermayoritas usaha-usaha mikro, home industry, petanai, hasil pertanian, masyarakat yang bermayoritas muslim sehingga mempermudah sosialisasinya, keterbatasan pemilik usaha-usaha mikro kecil serta masyarakat setempat berhubungan dengan lembaga keuangan karena tidak adanya lembaga keuangan di daerah setempat serta proses lama dan memerlukan aguan. Ancama (threat) pendiri BMT yaitu adanya pihak-pihak pesaing yaitu peminjaman liar yang menggunakan bunga sering disebut dengan lentenir, yang terlebih dahulu masyarakat mengenalnya, sumber daya manusia yang masih kurang dan lemah. Jadi dapat disimpulkan bahwa adanya potensi untuk pendirian Baitul Mal Wa Tamwil (BMT) di Desa Tolang Julu Kecamatan Sayur Matinggi Kabupaten Tapanuli Selatan, karena terdapat banyak kekuatan dan peluang yang ditemukan, dibandingkan dengan kelemahan dan ancaman yang ada.

\section{DAFTAR PUSTAKA / REFERENCES}

Abdul Qadim Zallum, Al-Amwal Fi Daulah Al-Khilafah, Beirut: Dar Al-ILM Li A-Malayin 1983.

Arifin Zainul, Memahami Bank Syariah, Jakarta: Alvabet, 2000.

Arikunto Suharsimi, Prosedur Penelitian Suatu Pendekatan, Jakarta: PT. Rineka Cipta, 2001. Bungin Burgan, Analisis Data Penelitian Kualitatif, Jakarta: PT. Raja Grafindo Persada, 2003. Data Perkembangan Koperasi Tahun 2017 dari BPS Tapanuli Selatan.

Gusfahmi, Pajak Menurut Strategi Itu Gampang, Jakarta: Dunia Cerdas, 2014.

Jmoleong Lexy, Metodelogi Penelitian Kualitatif, Bandung: PT Remaja Rosdakarya, 2004.

Kantor Camat Kecamatan Sayur Matinggi

Kautsar Riza Salman, Akuntansi Perbankan Syariah, Jakarta: Akademi Permata, 2012.

JISFIM: Journal of Islamic Social Finance Management, Volume 1, No 1 Tahun 2020 http://jurnal.iain-padangsidimpuan.ac.id/index.php/JISFIM 
155 Potensi Pendirian Baitul Mal Wa Tamwil (BMT) di Desa Tolang Julu Kecamatan Sayur Matinggi Kabupaten Tapanuli Selatan

Nurul huda, dkk., Baitul Mal Wa Tamwil, Jakarta: AMZAH, 2016.

Rangkuti Freddy, SWOT Balanced Scorecard, Jakarta : PT. Gramedia, 2011.

Shihab Quraish M. Tafsir Al-Mishbah Volume 5. Jakarta: Lentera Hati, 2002.

Shihab Quraish M. Tafsir Al-Mishbah Volume 13. Jakarta: Lentera Hati, 2002.

Soemitra Andri, Bank dan Lembaga Keuangan Syariah, Jakarta: Kencana, 2009.

Wawancara dengan Ibrahim Daulay sekretaris Desa Tolang Julu Kecamatan Sayur Matinggi Kabupaten Tapanuli Selatan pada tanggal 28 Maret 2019.

Wawancara dengan Ibu Irma Harahap selaku pemilik usah mikro kerajian rotan pada tanggal 7 Juli 2019. 